\title{
Utvikling av veilederkompetansen - en profesjonsetisk reise
}

Av Gunnvi Sæle Jokstad, førstelektor NLA Høgskolen

\section{Sammendrag}

Veiledning er en læringsarena og et redskap for å utvikle profesjonalitet i yrket. I veiledning kan det åpnes opp for refleksjon og oppdagelser som er annerledes enn ordinære samtaler mellom kollegaer. Denne studien undersøker hvordan studenter i faget Pedagogisk veiledning beskriver sin egen utvikling og læring i møte med arbeidskravet «Mitt pedagogiske credo». Det empiriske materialet er innhentet gjennom kvalitativ metode, bestående av analyse av dokumenter fra 15 studenter, både logger og refleksjonsnotat, samt fra et strukturert litteratursøk. Studien viser at studentene i møte med arbeidskravet utfordres på en slik måte at de endrer tenkning om veilederrollen og blir bevisstgjort sin egen væremåte. Den konkluderer med at studentene gjennom studiet også istandsettes til å videreutvikle profesjonsfellesskapet på eget arbeidssted.

Nøkkelord: veiledning, pedagogisk credo, profesjonsetikk, veilederutdanning, refleksjon, anerkjennelse

\section{Abstract}

Supervision is an area of learning and a tool for developing professionalism in the teaching vocation. Advising can facilitate reflection and discovery in a deeper way than ordinary conversations between colleagues. This study investigates how students enrolled in the course Pedagogical Advising 
describe their own development and learning gained through completion of the required assignment «My pedagogical creed». The empirical material is gathered through qualitative methods, consisting of analysis of documents from 15 students, both logs and reflective statements, in addition to a structured literature search. The study concludes that, when faced with this required assignment, students are challenged in such a way that their thinking about the role of the advisor changes and they become more aware of their own behavior. It concludes that the students through their studies also are enabled to further develop the collegial community at their own workplace.

Keywords: advising, pedagogical creed, adviser education, reflection, recognition

\section{Introduksjon}

Veiledning skal bidra til profesjonalisering, det vil si til utvikling og forsterking av yrkesutøvelsen. Dette er det bred faglig enighet om i veiledningslitteraturen (Bjerkholt, 2017; Østrem, 2015; Handal og Lauvås, 2014). Bjerkholt argumenterer for å erstatte yrkesfaglig veiledning med profesjonsveiledning og slik knytte den nærmere lærerutdanningen som en profesjonsutdanning (Bjerkholt, 2017, s. 225-226). Lærere som tar utdanning i veiledning hever sin egen profesjonalisering gjennom økt kunnskap og innsikt i fagfeltet, men er også sentrale aktører i andres profesjonalisering gjennom veiledningssamtaler. Studentene er da både i sentrum, som de lærende, men også samhandlende personer som er medierende redskaper for andres profesjonsutvikling. Læring gjennom veiledning skjer ved å igangsette andres refleksjon, for tanken både uttrykkes i ord og skapes gjennom den (Vygotsky, 1986/2000). Denne utviklingen skjer på to plan, først på et ytre plan for deretter å bevege seg på et indre menneskelig plan (Vygotsky, 1978). Å begi seg ut på en slik reise inn det ukjente og utrygge, krever mot. Læringsrammen er derfor av stor betydning. Veileder må være preget av en genuin interesse for den andre og vise respekt og anerkjennelse for den andres tanker og følelser i veiledningsprosessen. Slik kan tillit og mot til å framstille uferdige 
tanker få et handlingsrom, noe som er avgjørende for å kunne se og reflektere over muligheter. Da kan det skapes en grobunn for å utvikle profesjonelt skjønn, egenskapen som lærere kontinuerlig må utvikle.

Læreryrket er en skjønnsbasert yrkesutøvelse, i motsetning til evidensbasert, hevder Østrem (2015, s. 31) og skjønn «bærer i seg mulighetene for vilkårlighet, uforutsigbarhet, maktmisbruk og illegitim inntrengning i menneskers privatliv» (Grimen og Terum, 2009 i Østrem, 2015, s. 31). Også arbeidet som veileder krever utøvelse av skjønn (s. 32). Å legge til rette for å jobbe med seg selv som veileder og sin egen profesjonsetiske bevissthet; hvem jeg er og hvordan jeg vil oppleves, er derfor et helt sentralt fokusområde i veilederutdanningen.

Veilederstudiet, Pedagogisk veiledning, ved NLA Høgskolen (2019) er bygget opp av moduler på 15 studiepoeng. Majoriteten av studentene er lærere i skole og barnehage med mange års erfaring i yrket. De fleste er, eller ønsker å være, praksisveiledere for studenter i lærerutdanningen og veiledere for nyutdannede lærere. Studiet er samlingsbasert med ulike temadager for teorigjennomgang, refleksjon og øvelser, og blir supplert med obligatorisk mellomliggende arbeid i selvorganiserte basisgrupper der teori blir diskutert og praksisrelatert, og erfaringer og forståelser delt. Påbyggingsmodulen, som denne studien er hentet fra, vektlegger veilederens egen personlige utvikling der studenten får en stadig dypere bevissthet om veilederrollen og utvikler sensitivitet for den etiske dimensjonen i veiledningen (NLA høgskolen, 2019). Arbeidet med dette er knyttet an til erfaringslæring og aksjonslæring og munner ut i et arbeidskrav der studentene skal reflektere over egen utvikling som veileder og formulere sitt pedagogiske ståsted og grunnsyn, sitt "pedagogiske credo». Til dette tar de i bruk logger fra egen veiledningserfaring skrevet helt fra første undervisningsdag i modul 1. Teksten skal reflektere over hvordan ny kunnskap og innsikt kommer til uttrykk i deres handling som veiledere. Handlingsteori kan deles i bruksteori og uttalt teori, der bruksteorier er de som styrer handlingene våre i gitte situasjoner, mens uttalt teori er forsøket på å rettferdiggjøre og forklare en adferd (Argyris og Schön, 1978 i Gausdal, 2002; Grutle, 2018). Peter Senge, som bygger på Argyris og Schöns teori om organisasjonslæring, beskriver ulike elementer som må være til stede for å bygge og ivareta læring i organisasjoner. Ett av disse er personlig mestring, forklart som en hjørnestein og det «åndelige fundamentet» 
i en lærende organisasjon (Senge, 1990; Grutle, 2018). Personlig mestring innbefatter at den lærende driver med kontinuerlig kartlegging og utdyping av sine personlige visjoner og forholder seg til realiteter på en tålmodig og objektiv måte (Gausdal, 2002; Grutle, 2018). Dette tenker jeg kan være i tråd med det Bjørndal (2011a) beskriver som selvrelaterte egenskaper, «selvinnsikt i egne styrker og begrensninger» og overgripende kompetanse, forstått som «analytisk evne, kreativ og kritisk evne, evne til utvikling, klokskap, dømmekraft, etiske overveielser eller såkalt metakompetanse» (s. 153). «Læring skjer når vi foretar en effektiv handling, der vi avdekker og korrigerer feilene våre» (Argyris, 1993, s. 3, [min oversettelse] i Gausdal, 2002, s. 127). Det er studentenes refleksjon over tidligere handlingsmønstre og hvordan disse blir endret gjennom veilederstudiet vi utfordrer dem til å formulere gjennom sitt pedagogiske credo, en tenkning som har sitt utspring i John Dewey og hans essay «My Pedagogic Creed» (Dewey, 1897).

Begrepet kompetanse, fra latin «sammentreff, eller skikkethet» (Persvold, 2018), kan også forstås som dyktighet, kyndighet, ferdighet og mestring (Bø og Helle, 2008, s. 154). Det er kompetanse og hvordan denne kan komme til uttrykk i veiledningssituasjoner som en ferdighet og en kvalitet ved veiledning, artikkelen vil forsøke å gi et bilde av. Det finnes lite forskning på hva som kjennetegner veilederes utviklingsprosesser, og veiledningens komplekse virksomhet kan preges av både usikkerhet, avveininger og dilemmaer (Bjørndal, 2011b, s. 208). Ordet kvalitet, fra latin qualitas, kan oversettes med «hvordan sammensatt (...) beskaffenhet, art eller egenskap (Bjørdal, 2011c, s. 35). Det kan være på ulike nivå; input, prosess og output (s. 40). I denne studien er det ikke kvaliteten i veiledningen slik den kan oppleves for den veiledede som er i fokus, forstått som samtalens input og output, men derimot veileders kunnskap, holdning og væremåte som kan ha betydning for veiledningsprosessen, det gjøres rede for. Denne selvinnsikten i egen veilederkompetanse og evnen til metaperspektiv (Bjørndal, 2011a, s. 153) ordsettes i det avsluttende arbeidskravet; Reflekterende logg over egen utvikling og formulering av "mitt pedagogiske credo». Artikkelen er en redegjørelse for studentenes oppdagelser, utvikling og endret atferd gjennom veilederstudiet og forskningsspørsmål er: Hvordan kan arbeid med arbeidskravet "mitt pedagogiske credo" i veilederutdanningen heve kompetansen og bevisstgjøre studenter på sin rolle som veileder? 


\section{Metode}

For å undersøke studentenes utvikling av veilederkompetansen gjennom studiet og hvilke verdioppdagelser de gjør, ble det valgt en kvalitativ tilnærming, der hensikten er «å beskrive og forstå den andre» (Postholm og Jacobsen, 2018, s. 95). Denne konstruktivistiske metoden å få tak i andres forståelse av verden på, kan gjøres ved å gå inn i «hva de gjør og sier - la dem snakke med sine egne ord» (s. 99), her forstått som å få tak i deres egne beskrivelser gjennom deres stemmer. Det empiriske grunnlaget i denne studien er derfor innhentet gjennom litteratursøk og analyse av studenters prosessdokumenter i veilederutdanningen. Litteratursøket er gjennomført i basene Oria, Idunn og Google Scholar med søkeordene «veiledningskompetanse»; "profesjonsveiledning»; «verdier og holdninger i veiledningen»; "pedagogisk credo» med inklusjonskriterier norsk/svensk/dansk og engelsk språk og publiseringsårstall fra 2010. Litteratursøket er satt i dialog med annen kjent veiledningslitteratur og derved et valgt og begrenset utgangspunkt, eller det Postholm og Jacobsen (2018) kaller en forenkling av virkeligheten, men som gjør oss spesielt oppmerksomme på enkelte ting (s. 21).

Studentgruppen, bestående av 15 personer, var hovedsakelig kvinner i alderen 30-60 år og ansatt i skole eller barnehage. Studenttekstene bygger på omfattende notater over to studieår knyttet til veilederaktivitet på eget arbeidssted og i studentenes basisgruppe, samt en refleksjon og analyse av endringer i handling og tenkning. Arbeidskravet ble ferdigstilt i løpet av de to siste måneder av studiet Pedagogisk veiledning 1, modul $2 \mathrm{Meg}$ selv som veileder. Studenttekstene har blitt kategorisert med utgangspunkt i kategoriene «selvrelaterte egenskaper» og "overgripende kompetanse» (Bjørndal, 2011a, s. 152-153) for å finne spor etter beskrivelser av egen utvikling og ferdighet i å utføre en veiledning, samt holdning og verdier som skal gjennomsyre denne. Slike spor er funnet i alle 15 studenttekster og anvendt i drøftingen som en mulig indikator på læring, selv om læring ikke kan være direkte målbart (Postholm og Jacobsen, 2018, s. 19). Videre ble tekstene analysert for å finne utsagn knyttet til studentens tanker om profesjonsfellesskap på eget arbeidssted. Analysen ga følgende 3 funn; 1: Studentene utvider sin ferdighetskompetanse i møtet med refleksjon over egen læring; 2: Studentene utvider sin generiske og sin integrerte holistiske kompetanse 
i arbeidet med «mitt pedagogiske credo» og 3: Studentene har fătt en metalæring og ønsker å dele sin kompetanse i profesjonsfellesskapet på eget arbeidssted.

Det kan være svakheter ved studien da disse studenttekstene er skrevet som ledd i et arbeidskrav som skal godkjennes. Studentene kan da sette fokus på de verdier de tror forventes og holde tilbake tanker og refleksjoner de ikke tror anerkjennes. Studenttekstenes reliabilitet kan derfor være svekket. Likeledes kan min tolkning av deres stemme være begrenset og ufullkommen da jeg mer eller mindre bevisst kan ha søkt og valgt ut informasjon som styrker min oppfatning (Postholm og Jacobsen, 2018, s. 17). Likevel kan dette gi noe innsikt i studentenes selvrefleksjon og i endringer studentene gjør i løpet av studiet.

\section{Resultat og diskusjon}

Studiet gir innføring i hvordan en som lærende kan beskrive, reflektere og vurdere egen læring. Studentene møter visualisering av erfaringslæring via læringstrappen (Tiller, 2006, s. 39), erfaringssløyfen til Anthony Richards (Tiller, 2006, s. 31), Kolbs læringsteori (Bjørdal, 2011b, s. 213), og Dreyfus \& Dreyfus-modellen med sine fem nivåer fra nybegynner til læringsekspert (Tiller 2006, s. 35; Bjørndal 2011b, s. 211). Disse ulike modellene blir sentrale for studentene når de skal velge en måte å kommunisere på om sin kompetanseutvikling gjennom studiet. Dette knyttes også an til hvordan egen læring og refleksjon med kollegaer kan utvikles og forstås gjennom Wells' kunnskapsspiral (Grutle, 2018, s. 161), føre til organisasjonslæring slik Agryris og Schøn beskriver det (s. 131-147) og til lærende organisasjoner, slik det er tegnet ut av Peter Senge (s. 85-93). Alt starter med personlig mestring og evnen til å reflektere, utvikle og kommunisere denne. «Det handler om å utfordre seg selv på en grunnleggende måte», sier Tiller (2006, s. 54). Læring blir da en «aktiv, kreativ, følelsesmessig og intensjonal handling», sier han (s. 54). Derfor er arbeid i basisgrupper, samt krav om egen veiledning på arbeidsplassen sentrale aktiviteter i løpet av studiet.

$\AA$ jobbe med seg selv og lære av det, kan organiseres som et aksjonslæringsprosjekt. En holistisk kompetanseutvikling innbefatter fokus både på 
utvikling av relevante veiledningsferdigheter og på generiske aspekter (Bjørndal, 2011b, s. 209). Bjørndal begrunner dette med at veileders kompetanse ikke ensidig kan formidles utenfra, men fordrer en stadig aktiv og selvstendig læringsprosess i egen praksis (Bjørndal, 2011b). Slik kan den beskrives som å være et redskap for kontinuerlig lærings- og refleksjonsprosess, der en tar tak i egne omgivelser for å forbedre dem.

Credo-tenkningen har sitt utspring i John Dewey og hans essay «My Pedagogic Creed»(Dewey, 1897; Krogsmark, 2006). Studentene møter denne teksten sammen med artikler av Jan Gilje som definerer pedagogisk credo som trossetninger, noe som kan bli en ledestjerne i arbeidet (Gilje, 2015). I pedagogisk sammenheng kan det kobles til nærliggende begreper som pedagogisk grunnsyn, ethos og selvforståelse som han, med henvisning til Biesta, 2014, forklarer som «hvordan mennesket kan bli fritt, selvstendig, myndig og ansvarlig» gjennom verdier som «respekt, åpenhet, anerkjennelse av det enkelte mennesket som unik person og dets måte å være i og forholde seg til verden på» (Gilje, 2015, s. 27). Slik utvikles pedagogisk dømmekraft og leder til subjektivering, å respondere og ta ansvar (Biesta, 2014, s. 44).

Handling og tenkning er to komponenter som alltid hører sammen, ifølge Dewey (Krogsmark, 2006, s. 269). Slik tenkning og slike verdier er også helt sentrale og grunnleggende i profesjonsveiledning. En student sier: "Jeg har ikke vært særlig bevisst mitt pedagogiske credo før dette studiet, men jeg kommer til å være mye mer bevisst framover» (student 9). En slik refleksjon kan også knyttes an til å inneha en overgripende kompetanse (Bjørndal, 2011a, s. 153), som er en indikator på profesjonsutvikling (Gilje, 2015; Bjerkholt, 2017). Å arbeide med seg selv og den en vil være i møte med andre mennesker, er viktig og gjennom arbeidet med «mitt pedagogiske credo» redegjør studentene for endrede tanker om seg selv som veiledere og for en høyere etisk bevissthet om veileders ansvar.

Studentenes læring, slik de selv har reflektert over den i arbeidskravet, blir i det følgende presentert og analysert i 3 hovedkategorier.

Studentene utvider sin ferdighetskompetanse i møte med refleksjon over egen laring En veileder må inneha ulike kompetanser. Kompetansebegrepet kan forstås på ulike måte og blir også brukt på ulikt vis. Bjørndal (2011a, s. 141) for- 
klarer begrepet tradisjonelt som todelt; «hva en yrkesutøver i en stilling har rett og myndighet til å gjøre» og «yrkesutøvere som har de nødvendige kvalifikasjoner til å fylle en stilling». I senere tid har det blitt utvidet og retter nå ikke minst fokus på «evnen en yrkesutøver har til å håndtere et arbeidsliv og samfunn preget av kompleksitet og endring» (Kloeppen et al., 2008, i Bjørndal, 2011a, s. 141). Dette er interessant da denne forståelsen både kan brukes som forklaring på en veileders egen kompetanse og en begrunnelse for veileders virksomhet. Han beskriver videre at det kan skilles mellom minst tre ulike hovedsyn på kompetanse: Ferdighetstilnarmelse - generisk tilnarming og integrert/holistisk tilnarming (McMullan mfl. 2003, i Bjørndal, 2011a, s. 140). Ferdighetstilnærming er et snevert kompetansebegrep og setter fokus på adferd, konkrete ferdigheter, eller noe en person er, eller evner å gjøre. Dette gjenkjennes spesielt i håndverksmessige sider av yrkesutøvelsen og er naturlig å vektlegge innledningsvis i veilederutdanningen der det undervises og øves på ulike veiledningsferdigheter (Bjørdal, 2011a, s. 143). Teori er en måte å se noe på og reflektere over noe på (Postholm og Jacobsen, 2018, s. 20).

Når studentene skal beskrive hva de har lært gjennom studiet, er det tydelig at møtet med ny kunnskap, både gjennom teori og erfaringsdeling, er sentralt i deres profesjonelle utvikling. En student skriver: «Da jeg startet på veiledning modul 1, hadde jeg ikke gjort meg opp noen spesiell mening med hva veiledning av veisøker innebar. Jeg tenkte mer at dette kan jeg. Er det ikke bare å reflektere rundt ulike faktorer i yrket og se hvor man havner?» (student 14). En annen sier: «Min praksisteori er helt klart i endring, det merker jeg spesielt etter at jeg begynte på studiet» (student 6). Dette bekreftes også av utsagn fra student 8: «Jeg merker at jeg leser på en annen måte der jeg går dypt og personlig inn i litteraturen, uten å måtte forholde meg til at innholdet skal reproduseres i en testsituasjon.» Disse sitatene fra studentene viser at teori inviterer til refleksjon (Postholm og Jacobsen, 2018) og til å være en «reflektert praktiker» (Bjørndal, 2011a, s. 153).

Gjennomgående i så å si alle studenttekstene er at studiet har gitt verdifulle redskaper til å utøve veiledning: «Gjennom de første 15 studiepoengene i Pedagogisk veiledning hadde jeg tilegnet meg mer kunnskap og fått mer og bedre verktøy til å bruke når jeg skulle inn i veiledningssituasjoner» (student 13). Dette kan kobles til Bjørndal og hans beskrivelse av ferdighetstil- 
nærming; en adferd, eller en konkret evne til å gjøre noe (Bjørndal, 2011a, s. 143). En annen student skriver:

På modul 1 avsluttet jeg refleksjonsnotatet mitt med at jeg har utviklet meg som veileder, gjennom teori og erfaring med veiledning har jeg fått en større forståelse for hva veiledning kan være. (...). Jo mer kunnskap jeg fikk om veiledning jo mer forstod jeg at jeg ikke kunne. Nysgjerrigheten og ønsket om å videreutvikle meg som veileder resulterte i at jeg søkte meg inn på modul 2 (student 15).

At studiet hadde vært motiverende for videre læring, er tydelig, også etter endt utdanning. Student 11 sier: "Jeg gleder meg til fortsettelsen som veileder. Gleder meg til jeg skal begynne å ha studenter.» Den ferdighetskompetansen studentene uttrykker her er i tråd med det Bjørndal (2011a) beskriver som selvrelaterte egenskaper, «selvinnsikt i egne styrker og begrensninger». Arbeidet med den reflekterende loggen over egen utvikling og formulering av "pedagogisk credo" har utvidet studentenes praksisteori, gitt dem nye ferdigheter til å reflektere over, samt utviklet mot til å veilede. De har fătt oppleve å være reflekterte praktikere gjennom studiet og beskriver disse erfaringene og endringene som vesentlige. Det er grunn til å anta at arbeidet med "pedagogisk credo" har hevet deres kompetanse til å veilede.

Studentene utvider sin generiske og sin integrerte holistiske kompetanse gjennom arbeidet med "mitt pedagogisk credo»

En generisk tilnærming legger vekt på mer generelle egenskaper, eller attributter som anses overførbare til ulike situasjoner og kobles til kritisk tenkning, verdier og konstruktive holdninger (Bjørndal, 2011a, s. 145). Empati er en slik egenskap, sammen med evnen til desentrering, problemløsning, og andre attributter som integritet, humor, selvstendighet og samarbeid, for å nevne noen (s. 145). Den siste kompetansen Bjørndal trekker fram, integrert/holistisk tilnærmelse, rommer både konkrete egenskaper og generiske egenskaper. Han sier videre at en «slik overgripende kompetanse kan knyttes til begreper som praktisk klokskap, evnen til å vurdere, evne til etiske overveielser, evne til erfaringsbasert intuitiv handling og dømmekraft» og kobler den så videre til begrepet «den reflekterte praktiker» (s. 146). Det vil være 
naturlig å framheve nettopp denne kompetansen som sentral og ønskelig i profesjonsveiledning. Dette er også i tråd med veiledningens intensjon: "at veisøkeren skal stimuleres til en faglig og personlig utvikling» for å vinne «ny innsikt og ny erkjennelse knyttet til de fagområder som veiledningen setter fokus på» (Kristiansen, s. 28). Profesjonalitet blir da, sier hun «at man vil kunne stille noen krav til veilederens kompetanse, personlige integritet og den måten som veiledningen utøves på» (s. 32).

Dette summerer opp både den overordnede intensjonen med veilederutdanningen slik vi legger til rette for på undervisningssamlinger og er førende for de arbeidskravene studentene skal gjennomføre. Studentene har også ordsatt at studiet har endret deres måte å være på; «Gjennom studiet har jeg blitt bedre kjent med meg selv som veileder, og jeg vil påstå at jeg er mer 'årvåken' for mine sterke og svake sider» (student 3). En annen sier: «Etterhvert som jeg har gått pedagogisk veiledning har jeg blitt mer og mer bevisst på hvem jeg er, både som menneske, kollega, veisøker og veileder» (student 13). Dette leder an til det Bjørndal omtaler som generisk ferdighetstilnærming der det dreier seg om bevissthet om egen væremåte og egne holdninger og hvilke konsekvenser holdningen kan få for veisøker (Bjørndal, 2011a, s. 149). Studentene beskriver et tydelig fokusskifte fra seg selv og hva jeg skal gjøre, til den andre, den veiledede, og hvordan jeg kan være til hjelp for den andre.

Når det vises til konkrete erfaringer med sin egen utvikling som veileder og hvordan veilederrollen nå forstås, kan vi også si at dette har trekk av en integrert/holistisk ferdighetskompetanse (Bjørndal, 2011a). En student ordsetter dette slik: «Jeg ønsker å være allsidig og tilpasningsdyktig, slik at veisøker skal ha meningsfylte opplevelser med min veiledning. (...) at jeg er en person som er preget av egne valg, som igjen er etisk styrt» (student 5). Her vises det til at «redskap i verktøykassen» er en kilde å hente fra, men da alltid med en kontekstuell analyse som er preget av mot og vilje til å være ydmyk overfor samhandlingen, slik Larsen (2011) beskriver. En annen sier:

Veiledning skal føre til vekst og utvikling. Da må jeg som den profesjonelle (... ) ha god fagkompetanse (...) ha en teoretisk bakgrunn med ulike tilnærmingsmåter (...) ha gode kommunikasjonsferdigheter og god relasjonskompetanse (...) og være relasjonelt modig, for å kunne stå i saker som ikke alltid er behagelig (student 10). 
Begge disse studentkommentarene rommer det Bjørndal (2011a) kaller overgripende kompetanse, forstått som «analytisk evne, kreativ og kritisk evne, evne til utvikling, klokskap, dømmekraft, etiske overveielser eller såkalt metakompetanse» (s. 153). Slik selvrefleksivitet, utviklet gjennom studiet, viser også en integrert holistisk ferdighetsforståelse som er en kritisk faktor i all profesjonell utvikling (Bjørndal, 2011a, s. 153). Arbeidskravet «mitt pedagogiske credo» som er invitasjonen studentene får til å reflektere over seg selv som veileder, har tydelige beskrivelser som viser til klare endringer i både tanker og væremåte.

Skal en oppdagelse trekkes fram som mer gjennomgående enn andre, er det oppdagelsen av stillhet og lyttingens betydning. For å evne dette må veileder få en utvidet forståelse for hva som kan ligge til rette for slike oppdagelser. Ann Sofi Larsen (2011) har pekt på at dette henger sammen med veileders ansvar som lytter, for gjennom denne kan veisøker med sine erfaringer bli opplevd og sett som unik. Hun sammenligner dette med jazzens improvisasjon, «å ha mot og vilje til å lytte og være ydmyk overfor samhandling» (s. 50). Hun sier videre: «dette er veileders etiske ansvar i møtet med veisøker» og det som skal til «for å skape noe som ennå ikke er skapt» (s. 51).

Når lytting og tenkning kobles slik til ansvarlighet og krever stillhet, må evnen til å være i stillhetens rom, utvikles. Å arbeide med seg selv mot slike iboende egenskaper, er slik jeg forstår det, både en subjektivering og en generisk kompetanse og derved sentrale elementer i en profesjonsutvikling. En student sier: «Vi kan lytte med mer enn ørene; med øynene, lukt og andre sanser» (student 4). At dette er overordnet annet og blir oppfattet som et etisk prinsipp når en skal bistå til andres oppdagelse, viser at veileder ikke ser seg selv som svaret, men som et medierende redskap og derved underordner seg den hjelpetrengende. En annen student sier:

Det vil trolig kreve både erfaring og trygghet å tilrettelegge for en veiledningssamtale som flyter godt og som er levende. En veiledningssamtale som er naturlig, tåler stillhet.. (...). DA kan de indre stemmene komme, man får tid til å kjenne på kroppen og følelsene og man får tid til å reflektere for å komme nærmere ny innsikt og erkjennelse (student 7).

Og en annen sier videre: 
Etter at jeg har blitt bevisst på dette har kvaliteten på veiledningen blitt bedre. Jeg får tilbakemelding på at jeg oppleves mer tilstede i selve veiledningen og gir veisøker den tiden hun trenger. (...). Jeg må minne meg selv på at jeg ikke vet hvordan den andre personen egentlig har det. Jeg må respektere og akseptere henne for den hun er, jeg må vise empati og forståelse uten å gjøre det til mitt (student 4).

Studentene viser tydelig her både skjønn (Østrem, 2015) og et ansvar som lytter, og er ydmyke i forhold til samhandling, slik Larsen (2011, s. 50) trekker fram.

Eksemplene over viser at studentene har utviklet en sensibilitet for lyttingens muligheter og for betydningen av stillhetens rom. Slik kan denne egenskapen plasseres i både kategorien «selvrelaterte egenskaper» og i kategorien «overgripende kompetanse» (Bjørndal, 2011a, s. 153). Gjennom studiet har de utviklet kommunikasjonsferdigheter og metoder på den ene siden, forstått som en ferdighetstilnærming, og en overgripende forståelse knyttet til relasjon og holdning, på den andre siden. Dette må «sees som komplementere aspekter av veileders kompetanse», sier Bjørndal (2011a, s. 153). Studentene har erfart at vektleggingen av grunnleggende kommunikasjonsferdigheter supplert med utvidede ferdigheter til å anvende dette i mer utfordrende prosesser, har vært viktig å bli utfordret på. Det er derfor grunn til å anta at arbeidskravet «mitt pedagogiske credo» har vært med på å heve studentens bevissthet om sentrale verdier i veiledning.

Studentene har fätt en metalering og ønsker à dele sin nye kompetanse i profesjonsfellesskapet på eget arbeidssted

Bjerkholt (2017) hevder at ulike nasjonale og internasjonale studier viser at utbyttet av veiledning i praksisfeltet stort sett er knyttet til enkeltpersoners nytte (s. 43). Å ha en eksogen effekt, forklart som «å påvirke forhold, aktører og forhold utenfor selve veiledningssituasjonen», vil kunne føre til å heve refleksjonsnivået i organisasjonen (Holm mfl., 2015, referert i Bjerkholt, s. 43). Ved å vektlegge egen utvikling og læring i studiet som et utgangspunkt for og dermed en mulig initierende del av å være en lærende organisasjon, får studentene en oppdagelse av deres mulige betydning på egen arbeidsplass. 
Å dele erfaringene sine med kollegaer, som flere studenter beskriver det i arbeidskravet sitt, er et element i det Peter Senge definerer som å være en lærende organisasjon (Grutle, 2018, s. 85-87). Med utgangspunkt i personlig mestring kan felles visjon og læring i fellesskap, føre til læring i organisasjonen (Gausdal, 2002; Grutle, 2018). Studenter skriver: "Jeg har fătt et annet syn på veiledning og hvordan det kan brukes på arbeidsplassen» (student 4). En annen har fått et konkret oppdrag på arbeidsstedet sitt og skriver:

Det var da vendepunktet mitt kom. (...). De mente veiledning kunne øke kompetansen til hele personalet. Jeg kunne legge fram en plan om strukturert systematisk veiledning av personalet i barnehagen, og før jeg visste ordet av det har ledelsen bestemt seg for å satse på veiledning, der jeg skal få ansvaret for å veilede store deler av personalet (student 15).

Å ha personlig mestring og få anledning til å dele dette på arbeidsstedet slik at det kan føre til kollektiv læring og utvikling, er avgjørende for at organisasjoner skal utvikle seg profesjonelt. Dette er i tråd med forventningene i ny overordnet del, der det sies: «Skolen skal være et profesjonsfaglig fellesskap der lærere, ledere og andre ansatte reflekterer over felles verdier og vurderer og videreutvikler sin praksis» (Utdanningsdirektoratet, 2018). Lærere med faglig kompetanse i pedagogisk veiledning kan bli sentrale aktører for å nå dette målet. Brukes de aktivt på arbeidsplassen, kan deres nyervervede kompetanse få en ytterligere betydning for utviklingen av profesjonsfellesskapet, slik Bjerkholt etterlyser og kaller en eksogen effekt (Bjerkholt, 2017). Studentenes uttalelser kan tolkes som at de både er rede og villige til dette, og at arbeidet med arbeidskravet «mitt pedagogiske credo» har gitt dem kompetanse og bevisstgjort dem på sin rolle som tilrettelegger for andres profesjonelle utvikling.

«Det finnes lite forskning på hva som kjennetegner veilederes utviklingsprosesser», sier Cato Bjørndal (Bjørndal, 2011b, s. 208). I arbeidskravet har studentene gjort et forsøk på å beskrive dette og hvordan møtet med ny kunnskap også får noen personlige konsekvenser. «Etter at jeg har fått mer kunnskap om veilederrollen, er forskjellen nå fra tidligere at jeg stiller høyere krav til meg selv» (student 2). En annen student sier: 
... i veiledningssamtalen, oppstår det øyeblikk i kommunikasjonen der jeg kan skifte retning. (...). Å gjenkjenne slike veikryss og velge den mest hensiktsmessige veien videre i samtalen å utvikle et godt skjønn - er et personlig vekstmål for meg (student 8).

Dette kan kobles til begrepet forgreiningspunkt i samtalen (Jensen og Ulleberg, 2017, s. 109) og kan være et eksempel på at læreryrket er skjønnsbasert i motsetning til evidensbasert (Østrem, 2015, s. 31). Videre uttrykker en annen student seg slik:

Jeg ... ønsker å utvikle meg mot det Bjørndal skriver som kjennetegn på en god veileder: analytiske, kreative, kritiske evner, evne til utvikling, klokskap, dømmekraft, etisk kompass og metakompetanse (Bjørndal, 2011a, s.153). Jeg ser for meg at det kan ta tid før jeg kan identifisere meg med alle disse kjennetegnene, men jeg tenker at det er oppnåelig (student 12).

\section{Student 8 sier videre:}

Når jeg leser og relaterer til hendelser fra både veiledningssituasjoner og klasserommet, blir teksten min egen ved at jeg kommer den i møte. Ikke få ganger blir jeg så sterkt berørt at jeg enten ler høyt eller gråter inderlig.

Denne personlige erfaringen ordsetter dialogismens virkekraft (Bakhtin,1998) og beskriver også læringstrappen til Tiller (2006), der vi går fra løst prat om erfaringer - via erfaringer som ordnes og kobles, til det høyeste nivå der erfaringene kobles til teori. Da må de «gripe øyeblikket og ta imot de nye muligheter som øyeblikket åpner opp for. Dette krever vilje, mot og overskudd. Og, ikke minst, det krever nye ferdigheter» (Tiller, s. 180). Å ha evne til refleksjon i hverdagens øyeblikk kan denne læringshistorien si noe om:

Under frokosten tok ei jente mykje smør på brødskiva og på den ville ho ha skinkeost med majones på toppen. Eg sa til ho at majones ikkje kan smake godt oppå skinkeosten. Då fekk eg til svar det smakar godt i min munn (student 1).

Så reflekterer student 1 videre at kanskje er det slik med meningene våre også at vi ikke må være så redde for det som er nytt og ukjent for oss i møte med 
andre. Slik selvrefleksivitet viser at studenten har utviklet evne til å være analytisk og lærende og har innsikt i at empati, kontekst og egen forståelsesbakgrunn, preger kommunikasjon og forståelsesmønster (Bjørndal, 2011, s. 151).

For å gjøre oppdagelser kreves det et åpent sinn preget av anerkjennelse, respekt og ærbødighet. Skal vi heve vår profesjonalitet (Bjerkholt, 2017; Handal og Lauvås, 2014) og utvikle oss til autonome pedagoger som viser godt skjønn (Østrem, 2015), må vi lære av erfaringer vi gjør (Tiller, 2006), i situerte samhandlinger (Vygotsky, 1978). Da kan vi vinne ny innsikt (Kristiansen, 2008; Larsen, 2011). Studenttekstene viser hvordan arbeidet med arbeidskravet «mitt pedagogiske credo» (Dewey, 1897; Gilje, 2015) på ulike måter har utviklet deres pedagogiske dømmekraft (Biesta, 2014).

\section{Konklusjon}

Studien har gitt innsikt i hvordan studenter beskriver egen læring og utvikling og gjennom det hevet sin selvrefleksjon i møtet med studiet. De har ordsatt både selvrelaterte egenskaper og overgripende kompetanse, og gjennom arbeid med arbeidskravet «mitt pedagogiske credo» formulerer de sine pedagogiske og etiske visjoner. Slik har vi fått noe innsyn i hvordan studiets intensjon om læring og utvikling har festet seg som en profesjonsetisk reise. Studentene har tydelig endret fokus fra «hva de skal gjøre» som en ferdighet, til «hvordan de vil være», en person som anerkjenner den andres perspektiv, er aktivt lyttende og tåler stillhet. Et annet tydelig funn er at studentene gjerne vil dele den nyervervede kunnskapen i eget profesjonsfellesskap i skole og barnehage. Slik kan de bli aktive deltakere i utviklingen av profesjonsfellesskap og skoleutvikling, i tråd med ny Overordnet del-verdier og prinsipper $i$ grunnopplaringen, som beskriver nye prinsipper for skolens praksis knyttet til Læreplanverket Kunnskapsløftet 2020.

\section{Referanser}

Bakhtin, M. (1998). Spørsmålet om talegenrane (R. T. Slaatelid, overs.). Bergen: Ariadne Forlag. 
Biesta, G.J.J (2014). Utdanningens vidunderlige risiko. Bergen: Fagbokforlaget.

Bjerkholt, E. (2017). Profesjonsveiledning. Fra praktisk virksomhet til teoretisk felt. Oslo: Cappelen Damm akademisk.

Bjørndal, C.R.P. (2011a). Hva slags kompetanse trenger veilederen? I: T.J. Karlsen, (red.). Veiledning under nye vilkär. Skapende prosesser i møtet mellom veileder og veisøker. (s. 140-156). Oslo: Gyldendal Norsk Forlag A/S.

Bjørndal, C.R.P. (2011b). Hvordan kan veilederen utvikle sin kompetanse? I: T.J. Karlsen, (red.). Veiledning under nye vilkär. Skapende prosesser $i$ møtet mellom veileder og veisøker. (s. 208-231). Oslo: Gyldendal Norsk Forlag A/S.

Bjørndal, C.R.P. (2011c). Hva er kvalitet i veiledningen? I: T.J. Karlsen, (red.). Veiledning under nye vilkair. Skapende prosesser i møtet mellom veileder og veisøker. (s. 33-49). Oslo: Gyldendal Norsk Forlag A/S.

Bø, I. \& Helle, L. (2008). Pedagogisk ordbok. Praktisk oppslagsverk i pedagogikk, psykologi og sosiologi. (2. utg.) Oslo: Universitetsforlaget.

Dewey, J. (1897). My Pedagogical Creed. School Journal (54) 77-80. Hentet fra http://dewey.pragmatism.org/creed.htm

Eide, S.B. (2012). Individuelt ansvar og sløvhet i profesjonsutøvelse. Etikk i Praksis - Nordic Journal of Applied Ethics, 6(2) 64-79. Hentet fra https://doi.org/10.5324/eip.v6i2.1785

Gausdal, B. (2002). Læring i organisasjonar. I: Nordhaug, O. (2002). Strategisk personalledelse. Utvalgte emner. (2. utg.) Oslo: Universitetsforlaget.

Gilje, J. (2015). Kan pedagogisk credo-tenkning selvstendiggjøre personen og pedagogen? I: P.O. Brunstad, S.M. Reindal \& H. Sæverot, (red.). Eksistens og pedagogikk. En samtale om pedagogikkens oppgave (s. 23-39). Oslo: Universitetsforlaget.

Grutle, B. (2018). Profesjonsfellesskap og skoleutvikling. Oslo: Cappelen Damm akademisk.

Handal, G. \& Lauvås, P. (2014). Veiledning og praktisk yrkesteori. (3. utg.). Oslo: Cappelen Damm akademisk.

Jensen, P. \& Ulleberg, I. (2017). Systemisk veiledning i profesjonell praksis. Bergen: Fagbokforlaget. 
Kristiansen, A. (2008). Hva skiller en veiledningssamtale fra andre samtaler? Veiledningssamtalens egenart og etiske utfordringer. I: S.B. Eide, H.H. Grelland, A. Kristiansen, H.I. Sævareid \& D.G. Aasland. Til den andres beste. En bok om veiledningens etikk. (s. 24-40). Oslo: Gyldendal Norsk Forlag A/S.

Krogsmark, T. (2006). Den tidløse pedagogikken. (Ane Sjøbu, overs.). Bergen: Fagbokforlaget.

Larsen, A.S. (2011). Å lytte til det uforutsette, det ukjente og det uforutsigbare. I: Karlsen, T.J. (red.). Veiledning under nye vilkair. Skapende prosesser $i$ møtet mellom veileder og veisøker. (s. 50-67). Oslo: Gyldendal Norsk Forlag A/S.

NLA Høgskolen (2019). Pedagogisk veiledning. Hentet fra https://www.nla.no/studietilbud/studieprogrammer/pedagogisk-veiledning

Persvold, A.Z. (2018, 3. mai). Kompetanse. I: Store norske leksikon. Hentet fra https://snl.no/kompetanse

Postholm, M.B. \&. Jacobsen, D.I. (2018). Forskningsmetode for masterstudenter i larerutdanning. Oslo: Cappelen Damm akademisk.

Tiller, T. (2006). Aksjonslering - forskende partnerskap i skolen. Motoren i det nye leringsløftet. Kristiansand: Høyskoleforlaget.

Utdanningsdirektoratet (2018). Overordnet del. Profesjonsfellesskap og skoleutvikling. Hentet fra https://www.udir.no/lk20/overordnet-del/3.-prinsipper-for-skolens-praksis/3.5-profesjonsfellesskap-og-skoleutvikling

Vygotsky, L.S. (1978). Mind in Society. The Development of Higher Psychological Processes. Cambridge: Harvard University Press.

Vygotsky, L.S. (1986/2000). Thought and Language. Cambridge, MA: MIT Press.

Østrem, S. (2015). Veiledning som redskap i profesjonell utvikling. Om yrkesfaglig veiledning for larere. Oslo: Cappelen Damm akademisk. 